\title{
Toxicity assessment of five emerging pollutants, alone and in binary or ternary mixtures, towards three aquatic organisms
}

\author{
Di Poi Carole ${ }^{1,2,{ }^{*}}$, Costil Katherine ${ }^{1}$, Bouchart Valérie ${ }^{3}$, Halm-Lemeille Marie-Pierre ${ }^{4,5}$
}

\author{
1 UMR BOREA, MNHN, UPMC, UCBN, CNRS-7208, IRD-207, SFR ICOREUniversité de Caen \\ NormandieCaen Cedex,France \\ 2 Ifremer, LEMAR UMR 6539 CNRS/UBO/IRD/Ifremer, Centre de BretagnePlouzané,France \\ ${ }^{3}$ Laboratoire LABÉO Frank DuncombeCaen, Cedex 4,France \\ ${ }^{4}$ CERMN, UNICAEN EA 4258. FR CNRS 3038 INC3M SF 4206 ICOREUniversité de Caen \\ NormandieCaen Cedex,France \\ ${ }^{5}$ Ifremer, LERPort en Bessin,France \\ *Corresponding author : Carole Di Poi, email address : carole.dipoi@ifremer.fr
}

\begin{abstract}
:
Despite a growing scientific attention on ecological impact of emerging pollutants (EPs) such as pharmaceuticals, personal care products, and pesticides, knowledge gaps remain regarding mixture toxicity and effects on aquatic organisms. Several EPs were screened in seawater (Normandy, France), and the ecotoxicity of five compounds, chosen on their occurrence in ecosystems and use worldwide, was assessed and were the biocides methylparaben (MP) and triclosan (TCS), a pesticide degradation product (AMPA), and the pharmaceuticals venlafaxine (VEN) and carbamazepine (CBZ). The acute or sub-chronic toxicity, alone or in binary/ternary mixtures of three of them (CBZ, AMPA, and MP), was assessed on one marine and two freshwater organisms: Crassostrea gigas, Pseudokirchneriella subcapitata, and Daphnia magna. TCS and AMPA were, respectively, the most $\left(\mathrm{EC}_{50}<1 \mathrm{mg} \mathrm{L}^{-1}\right)$ and the least $\left(E_{50}>50 \mathrm{mg} \mathrm{L}^{-1}\right)$ toxic chemicals for the four endpoints (algal growth inhibition, daphnia immobilization, oyster embryotoxicity, and metamorphosis). The anxiolytic VEN (EC $50<\mathrm{mg} \mathrm{L}^{-1}$ ) was particularly toxic to oyster larvae showing sensitivity difference between freshwater and marine organisms. If all the mixtures appeared to be in the same range of toxicity, the joint-toxic effects mainly led to synergistic or antagonistic interactions compared to single-compound toxicity. The data also highlighted species-dependent differing models of toxicity and underscored the need for an awareness of cocktail effects for better ecological risk assessment.
\end{abstract}

Keywords: Pharmaceuticals, Personal care products, Pesticides, Mixture and single-compound toxicity, Freshwater species, Marine bivalve 


\section{Introduction}

Nowadays, over a thousand emerging pollutants (EPs), their metabolites and their transformation products are present in aquatic environments worldwide (NORMAN 2016). However, they are currently not included in routine monitoring programs, and their fate, behaviour and ecotoxicological effects remain little known. Amongst EPs, the classes of Pharmaceuticals and Personal-Care Products (PPCPs) and polar pesticides are predominant in European hydrosystems (NORMAN 2016). They received a growing scientific attention in the last decades in particular because of their intrinsic properties to cause biological effects (e.g., Daughton and Ternes 1999; Boxall et al. 2012; Fabbri and Franzellitti 2016). They are found ubiquitously in all aquatic compartments at concentrations reaching few ng. $\mathrm{L}^{-1}$ in coastal marine waters of developed countries (Gaw et al. 2014; Fabbri and Franzellitti 2016) to up to several dozen $\mu \mathrm{g} . \mathrm{L}^{-1}$ in surface waters and urban effluents (e.g., Daughton and Ternes 1999; Kolpin et al. 2002; Munaron et al. 2012; Chiffre et al. 2016); exceeding sometimes the safety threshold for predicted environmental concentrations in surface waters of $0.01 \mu \mathrm{g} . \mathrm{L}^{-1}$ (EMEA 2006). In addition, because of their physical and chemical properties $\left(\log K_{\mathrm{ow}}>3\right)$ and/or because of their continual infusion into the aquatic media, some PPCPs and pesticides may persist in environment and bioaccumulate in animal tissues (e.g. Álvarez-Muñoz et al. 2015a,b; Fabbri and Franzellitti 2016). Numerous compounds like antimicrobial disinfectants and paraben preservatives, used for example in cosmetic, pharmaceutical or food industries, rise concern in particular because of their suspected or proven endocrine effects in aquatic organisms (Brausch and Rand 2011); and thus need to be investigated in risk assessments. One can cite the antimicrobial triclosan (a diphenyl ether derivative) which is highly prevalent in aquatic environments throughout the world (Kolpin et al. 2002; Halden and Paull 2005), and suggested as a candidate priority substance (von der Ohe et al. 2012). The continuous release of pharmaceutical residues also becomes an environmental issue because they can 
behave as persistent compounds (Daughton and Ternes 1999), and concern has been voiced for the psychotropic drugs for which global consumption is increasing (Beausse 2004). Antiepileptics were among the most predominant therapeutic classes prescribed in several countries at the end of the 90s (Beausse 2004) and nowadays, carbamazepine is increasingly found in aquatic environments (Ternes 1998; Daughton and Ternes 1999; Seiler et al. 1999; Chiffre et al. 2016). This compound is even in the top 5 of the most occurring molecules in the marine environment worldwide (Fabbri and Franzellitti 2016). Between 1980 and 2001 in France, the prescription of antidepressants grew sevenfold, with venlafaxine being one of the most consumed molecules (Olié et al. 2002; Amar and Balsan 2004; ANSM 2012). This compound was found to be the most prevalent antidepressant in the Orne river (France) at the ng. $\mathrm{L}^{-1}$ range, and is even detected at sea, $17 \mathrm{~km}$ downstream the point of release (Minguez et al. 2016). Finally there is an increase in the use of pesticides worldwide, which is seen as a consequence of human population growth and its impact has reached global significance (Köhler and Triebskorn 2013). For example, the glyphosate-based formulations are amongst the most used herbicides in the world (Howe et al. 2004). Glyphosate has often been considered relatively non-toxic for humans and fauna (Giesy et al. 2000; Williams et al. 2000) with an environmentally low impact because of its rapid biodegradation and strong adsorption to soil particles (Agritox 2016; PPDB 2016). However, a degradation product, the aminomethylphosphonic acid (AMPA), was detected much more frequently in US streams and treatment plant effluents than glyphosate itself (present in $67.5 \%$ of the samples $v s 17.5 \%$, respectively; Kolpin et al. 2006) and AMPA is, even now, the most prevalent pesticide molecule in French stream waters (Botta et al. 2009; Commissariat Général au Développement Durable 2013).

Quantification of emerging pollutants in the different environmental compartments is essential for gaining knowledge on their occurrence and fate. In this study, we first performed 
an environmental screening of 21 molecules belonging to three classes of emerging compounds (pharmaceuticals, biocides and pesticides) in coastal seawaters. Based on our screening and on literature (data about occurrence and use worldwide), we tested the ecotoxicity of five molecules that were: (1) the anxiolytic venlafaxine (VEN) and the antiepileptic carbamazepine (CBZ); (2) the preservative methylparaben (MP) and the antimicrobial triclosan (TCS); and (3) the aminomethylphosphonic acid (AMPA). In order to obtain ecologically-relevant data on their potential ecological risks, we studied the toxicity of these five chemicals alone as well as the joint-action toxicity of three of them (CBZ, MP and AMPA) in binary and ternary combinations to mimic environmentally realistic mixtures. We carried out several bioassays using two freshwater and one marine species according to standard guidelines: embryotoxicity and metamorphosis test on the Pacific oyster Crassostrea gigas, a worldwide leading aquaculture species, whose the larvae are particularly susceptible to a large range of pollutants (e.g., Mottier et al. 2013; Di Poi et al. 2014); growth inhibition assay on the freshwater green alga Pseudokirchneriella subcapitata, which is an important primary producer (Blaise and Vasseur 2005); and immobilization test on the freshwater crustacean Daphnia magna, which occupies a key position in the aquatic food web by linking primary and secondary productions (Dodson and Hanazato 1995; Tatarazako and Oda 2007; Miner et al. 2012). With regard to the constitution of the mixture (different families of molecules and different biological targets), we hypothesized that the combined effects will lead to synergistic interactions between the compounds, i.e. the toxic effects caused by the mixture will exceed the sum of effects of the separate constituents, and aimed to bring new insights in the ecotoxicological risk assessment of emerging pollutants. 


\section{Material and methods}

\section{Analytical quantification in seawater}

In October 2014, we conducted an environmental screening of 21 emerging compounds (Table 1) that belonged to three different chemical classes ( 9 pharmaceutical products, 9 biocides, 2 pesticides and 1 degradation product) in seawater samples collected in the district of Meuvaines $\left.49^{\circ} 20^{\prime} 38^{\prime \prime} \mathrm{N} 0^{\circ} 34^{\prime} 19^{\prime \prime} \mathrm{W}\right) /$ Ver-sur-Mer $\left(49^{\circ} 20^{\prime} 45^{\prime \prime} \mathrm{N} 0^{\circ} 31^{\prime} 99^{\prime \prime} \mathrm{W}\right)$, an important shellfish harvesting area on the Normandy coastline (Figure 1).

Pesticides (glyphosate, AMPA, glufosinate) were quantified by UPLC and Fluorometric detection (in according with NF ISO 21458) using UPLC Acquity with FLR detector

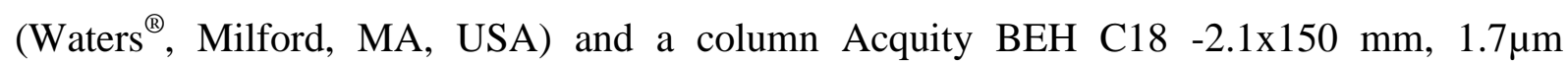
(Waters ${ }^{\circledR}$, Milford, MA, USA). The 18 other compounds were extracted from 1 litre of sampled seawater with Solid Phase Extraction (HLB Oasis 200mg; Waters ${ }^{\circledR}$, Milford, MA, USA). The extract was then analysed by ultra-performance liquid chromatography (LC) and MS-MS detection using a UPLC Agilent 1290 Infinity with Agilent 6460 Triple Quadrupole (Agilent Technologies ${ }^{\circledR}$, Santa Clara, USA) and a Column Acquity BEH C18 -2.1 mm×150 mm, $1.7 \mu \mathrm{m}$ column (Waters ${ }^{\circledR}$, Milford, MA, USA). Two different chromatographic methods were used: for the biocides quantification, the gradient mobile phase was methanol and MilliQ ultrapure water and for pharmaceuticals, the gradient mobile phase was prepared with acetonitrile or MilliQ ultrapure water acidified (0.05\% formic acid). For each compound, an isotopically-labeled surrogate (internal standard) was associated for LC-MS-MS quantification in Multiple Reaction Monitoring Analysis (Supplemental Data, Table S1). 


\section{Laboratory bioassays}

\section{Chemical products}

Based first on the concentration levels of the compounds in the harvesting area (Table 1) and/or based on consumption data and occurrence worldwide when necessary, we analyzed the toxicity of five compounds: the pharmaceuticals venlafaxine (VEN; anxiolytic) and carbamazepine (CBZ; anticonvulsant and antiepileptic), the biocides methylparaben (MP; preservative) and triclosan (TCS; antimicrobial), and a glyphosate degradation product, the aminomethylphosphonic acid (AMPA). To mimic environmentally realistic mixtures of emerging pollutants, we selected one compound in each chemical class and were: CBZ, MP and AMPA mixed in binary and ternary combinations.

The molecules were purchased in analytical grade (purity > 98\%) from Sigma Aldrich ${ }^{\circledR}(\mathrm{St}$ Louis, MO, USA): VEN (CAS No. 99300-78-4), CBZ (CAS No. 298-46-4), MP (CAS No. 99-76-3), TCS (CAS No. 3390-34-5) and AMPA (CAS No. 1066-51-9). For the preparation of the test solutions, the chemicals were dissolved in the appropriate medium; while AMPA and VEN were soluble in water, the carrier solvent dimethyl sulfoxide (DMSO; CAS No. 6768-5) was used to dissolve MP, TCS, and CBZ in the solutions with a final proportion comprised between $0.005 \%$ and $0.1 \%$ of the volume at most. In each bioassay, the effect of DMSO was also tested in parallel to controls (i.e. seawater or culture medium with no added chemicals) and no effect was observed.

\section{Test solutions}

For the compounds alone, the bioassays were first applied using a broad range of concentrations from $1 \times 10^{-7}$ for the minimum to $1 \times 10^{7} \mu \mathrm{g} \cdot \mathrm{L}^{-1}$ at most by serial dilutions with a factor 10. Then the concentration arrays were narrowed with a dilution factor of 2.5 and 
lowered when necessary. The range was not narrowed when the $\mathrm{EC}_{50}$ values was above 100 mg. $\mathrm{L}^{-1}$. Based on the $\mathrm{EC}_{50}$ values of the molecules alone, the mixtures were realized by using the lowest toxic compounds of each class of pollutants in order to test for the hypothesis of an enhancement of toxicity (additive or synergistic action) when mixed together. Three binary mixtures and one ternary mixture were tested and the combinations were: Mixture $1=\mathrm{CBZ}+$ $\mathrm{MP}+\mathrm{AMPA} ;$ Mixture $2=\mathrm{CBZ}+\mathrm{MP}$; Mixture $3=\mathrm{CBZ}+\mathrm{AMPA}$; Mixture $4=\mathrm{AMPA}+$ MP. The toxicity of these mixtures was tested by sequential dilutions ranging from the actual environmental concentrations (i.e. $1 \mathrm{X}$ ), by taking the highest concentration for each compound (given in Table 1), to up to $1 \times 10^{7} \mathrm{X}$ with a dilution factor of 10 . The range was eventually narrowed with a factor of 2.5 or lowered when relevant. Because AMPA was not detected at the time of the sampling (October 2014), the environmental level of 500 ng.L $\mathrm{L}^{-1}$ was used (average measured after monthly quantification from between February to November 2014; Bouchart and Houssin 2014) to make the concentration range.

\section{Algal growth inhibition tests}

Freshwater algal tests were conducted following the NF EN ISO 8692 guideline (2012) using the microalga Pseudokirchneriella subcapitata AC152 obtained from Algobank ${ }^{\circledR}$ (Caen, France). We used the ISO 8692 standard rather than the OECD 201 (2006); however, the two methods are quite similar in terms of experimental conditions (see the document ENV/JM/MONO(2008)28 for further details on comparisons). We performed the tests in 96well cell culture plates instead of glass vessels in order to miniaturize the assays. The algal growth inhibition tests were conducted at $20 \pm 1^{\circ} \mathrm{C}$ with continuous shaking at $100 \mathrm{rpm}$ and luminosity (white light at 4,000 lux). Each substance, the medium and the algal inoculums were mixed to obtain an initial algal concentration of $10^{4}$ cells. $\mathrm{mL}^{-1}$ in $0.21 \mathrm{~mL}$ of bioassay 
volume. At least three replicates were used per concentration. Cell density was measured after $72 \mathrm{~h}$ of exposure. The results were expressed as average growth rates calculated from cell numbers based on chlorophyll fluorescence measurements (680 nm, TECAN Infinite ${ }^{\circledR}$ M200 microplate reader). The $\%$ of inhibition of average specific growth relative to controls were calculated for each concentration. All the controls (chemical-free culture medium and DMSO) met the acceptability criteria, i.e. an algal growth factor higher than 32 after $72 \mathrm{~h}$ from the initial concentration, and toxicity for the reference chemical potassium dichromate $\left(\mathrm{K}_{2} \mathrm{Cr}_{2} \mathrm{O}_{7}\right)$ was between 0.24 and $1.03 \mathrm{mg} . \mathrm{L}^{-1}$ for the $24 \mathrm{~h}-\mathrm{EC}_{50}$.

\section{Daphnia magna acute immobilization tests}

Immobilization tests were conducted following the guideline NF EN ISO 6341 (1996) using the water flea Daphnia magna Straus (Cladocera, Crustacea) obtained from the Institut National de 1'Environnement Industriel et des Risques (INERIS, Verneuil-en Halatte, France) and from the Labéo Franck Duncombe (Saint-Contest, France). We also used the ISO 6341 standard rather than the OECD 202 (2004) but the two methods are similar (see the document ENV/JM/MONO(2008)28 for further details on comparisons). Tests were ran using neonates less than 24 h-old obtained from continuous parthenogenetic reproduction of adult females. Static $48 \mathrm{~h}$-toxicity tests were performed in $10 \mathrm{~mL}$-culture volume at a temperature of $20 \pm$ $1{ }^{\circ} \mathrm{C}$, without food addition and in total darkness. At least three replicates were used per concentration with 5 neonates per replicate. Immobility (i.e., no movement following shaking of the test pill bottles) was the endpoint for effect calculation observed at $48 \mathrm{~h}$. All the controls (chemical-free culture medium and DMSO) met the acceptability criteria (no more than $10 \%$ mortality) and the $24 \mathrm{~h}-\mathrm{EC}_{50}$ for the reference chemical potassium dichromate $\left(\mathrm{K}_{2} \mathrm{Cr}_{2} \mathrm{O}_{7}\right)$ ranged between 0.6 and $2.1 \mathrm{mg} \cdot \mathrm{L}^{-1}$. 


\section{Oyster embryo-larval development and metamorphosis tests}

The methods are fully described in Di Poi et al. (2014).

Embryotoxicity. Acute tests were conducted following the standardized AFNOR XP-T-90-382 procedure (2009) and conditioned oyster genitors were provided by the Guernsey Sea Farm hatchery Ltd ${ }^{\circledR}$ (Guernsey, UK). Spawning was induced by thermic stimulation (succession of 30 -min cold and warm bathes of 16 and $28^{\circ} \mathrm{C}$, respectively) in filtered seawater, and the eggs were fertilized with sperm at a 1:6 (egg:sperm) ratio. Twenty minutes post-fertilization, embryos were distributed into glass pillboxes at a density of 60,000 embryos. $\mathrm{L}^{-1}$, and exposed in a final volume of $25 \mathrm{~mL}$ of filtered and sterilized natural seawater $\left(0.22 \mu \mathrm{m}\right.$; Steritop ${ }^{\circledR}$ Millepore) for $36 \mathrm{~h}$ at $22 \pm 1{ }^{\circ} \mathrm{C}$ in dark. Observations were conducted on fixed organisms ( $8 \%$ formalin solution) with an inverted binocular microscope (Leica ${ }^{\circledR}$ DM IRB), and the net percentage of normal development (NPN), i.e. number of normal D-shaped larvae vs. number of embryos and abnormal larvae adjusted to the controls, was calculated. Each concentration was tested at least in triplicate. All bioassays met the acceptability criteria with $\mathrm{EC}_{50}$ of $\mathrm{Cu}^{2+}$ between 6-16 $\mu \mathrm{g} . \mathrm{L}^{-1}$ and mean rates of normal development for the different control groups reaching $78.5 \pm 1.6 \%$ for chemical-free seawater controls, $75.8 \pm 2.1 \%, 79.7 \pm 3.3 \%, 79.3 \pm$ $2.1 \%$ for $0.005 \%, 0.01 \%$ and $0.1 \%$ DMSO controls, respectively.

Metamorphosis. Twenty-one day-old pediveliger larvae were provided by the SATMAR hatchery ${ }^{\circledR}$ (Societé ATlantique of MARiculture, Gatteville-le-Phare, France). Larvae were exposed in 12-well culture plates with a density of 50-80 individuals per well in a final volume of $1.5 \mathrm{~mL}$ of filtered and sterilized seawater $\left(0.22 \mu \mathrm{m}\right.$; Steritop ${ }^{\circledR}$ Millepore $)$ for $24 \mathrm{~h}$ at $22 \pm 1^{\circ} \mathrm{C}$ in dark. Epinephrine at $10^{-4} \mathrm{M}$ (CAS No. 51-43-4; Sigma Aldrich ${ }^{\circledR}$, Saint-Louis, MO, USA) was added to promote larval settlement and metamorphosis (Coon and Bonar, 1987). Observations were conducted on fixed organisms ( $8 \%$ formalin solution) with an 
inverted binocular microscope (Leica ${ }^{\circledR}$ DM IRB). The net percentage of metamorphosis rate (NPM) was assessed by counting the number of metamorphosed larvae vs. total number of dead larvae and non-metamorphosed larvae adjusted to the controls. Each concentration was tested at least in triplicate. Mean rates of metamorphosis for the different control groups reached $80.4 \pm 1.8 \%$ for chemical-free seawater controls, $77.7 \pm 2.0 \%, 83.1 \pm 2.8 \%, 73.0 \pm$ $1.7 \%$ for $0.005 \%, 0.01 \%$ and $0.1 \%$ DMSO controls, respectively.

\section{Data treatment and statistics}

\section{Dose-response data analysis}

For each endpoint, non-linear regression using the hill equation was used to calculate Effective Concentrations $\left(\mathrm{EC}_{10}, \mathrm{EC}_{20}, \mathrm{EC}_{50}\right)$ based on nominal concentrations. These regressions were obtained using the Excel ${ }^{\mathrm{TM}}$ macro REGTOX (Vindimian 2012). Estimates of $\mathrm{EC}_{10}$ and $\mathrm{EC}_{20}$ were taken as equivalent to No Observed Effect Concentration (NOEC), and Lowest Observed Effect Concentration (LOEC), respectively as suggested in OECD guidelines (OECD 201 2006). For each bioassay, toxicity between the four mixtures was compared using a non-parametric Kruskal-Wallis test based on raw data (Supplemental Data, Table S2) following normality tests of Shapiro-Wilk. $p<0.05$ was chosen as the significance level.

\section{Toxicity of mixtures}

Joint-action toxicity data were analyzed based on the Synergistic Ratio (SR) model after Hewlett and Plackett (1959):

$$
\text { SR index }=\frac{\text { EC50 of Chemical acting alone }}{\text { EC50 of Chemical }+ \text { additive (mixture) }}
$$


where $\mathrm{EC}_{50}$ of the mixture obtained in $\mathrm{X}$ were recalculated by taking into account the actual concentrations of each compound used in the mixture in $\mathrm{mg} . \mathrm{L}^{-1}$; and $\mathrm{SR}=1$ describes that the joint action is additive; $\mathrm{SR}<1$ describes antagonism; $\mathrm{SR}>1$ describes synergism.

\section{Results}

\section{Occurrence of emerging compounds in seawater}

The concentrations of the 21 compounds screened in coastal waters are reported in Table 1 . For pharmaceutical residues, the levels of contamination were equivalent between the two sampling sites. Amongst the 9 molecules screened, 5 pharmaceuticals were quantified at concentrations ranging from 0.81 to $1.74 \mathrm{ng} . \mathrm{L}^{-1}$; the highest concentration molecule was oxazepam (1.61 ng. $\mathrm{L}^{-1}$ in average). The concentrations of biocides were higher at Meuvaines than at Ver-sur-Mer for 5 biocidal compounds; and levels of methylparaben and triclosan were the most elevated at both sites (averages of $11.12 \mathrm{ng} . \mathrm{L}^{-1}$ and $9.13 \mathrm{ng} . \mathrm{L}^{-1}$, respectively). Concentrations of the two pesticides (glyphosate, glufosinate) and of AMPA were under the limit of quantification (0.05 ng. $\left.\mathrm{L}^{-1}\right)$ at both sites at the time of the sampling (October 2014).

\section{Toxicity of single molecules}

The toxicity was evaluated for the five molecules based on nominal concentrations (Table 2). According to the ecotoxicological parameters $\left(\mathrm{EC}_{\mathrm{x}}\right)$, triclosan and AMPA were, respectively, the most and the least toxic compounds for all species. The $\mathrm{EC}_{\mathrm{x}}$ values for each compound were in the same range for the two freshwater species. They were as low as $0.03 \mathrm{mg} . \mathrm{L}^{-1}$ in $P$. subcapitata and $0.23 \mathrm{mg} . \mathrm{L}^{-1}$ D. magna for triclosan, to higher than $100 \mathrm{mg} . \mathrm{L}^{-1}$ for carbamazepine and AMPA. The $\mathrm{EC}_{50}$ values of venlafaxine and methyl-paraben were, respectively, $47.58 \mathrm{mg} . \mathrm{L}^{-1}$ and $35.25 \mathrm{mg} . \mathrm{L}^{-1}$ in green algae and $141.28 \mathrm{mg} . \mathrm{L}^{-1}$ and $41.23 \mathrm{mg} . \mathrm{L}^{-}$ 
${ }^{1}$ in the daphnia. In the $C$. gigas embryotoxicity test, the $\mathrm{EC}_{50}$ values ranged from $0.04 \mathrm{mg} . \mathrm{L}^{-1}$ for triclosan up to $50.78 \mathrm{mg} \cdot \mathrm{L}^{-1}$ for AMPA. In the metamorphosis test, triclosan and venlafaxine were the most toxic compounds $\left(\mathrm{EC}_{50}=0.34\right.$ and $0.31 \mathrm{mg} \cdot \mathrm{L}^{-1}$, respectively). Except for triclosan which appeared highly toxic whatever the organism tested, the early life stages of $C$. gigas were more sensitive than freshwater species $\left(\mathrm{EC}_{\mathrm{X}} \mathrm{s}\right.$ in $C$. gigas $<\mathrm{EC}_{\mathrm{X}} \mathrm{s}$ in $D$. magna and $P$. subcapitata).

\section{Joint-action toxicity of mixtures}

The toxicity of mixtures varied from $1,793 \mathrm{X}$ in $P$. subcapitata to more than $900,000 \mathrm{X}$ in $C$. gigas and D. magna (Table 3). Based on $\mathrm{EC}_{50} \mathrm{~s}$ and for the four bioassays, the mixtures can be ranked as: mixture $2(\mathrm{MP}+\mathrm{CBZ})<\operatorname{mixture} 3(\mathrm{AMPA}+\mathrm{CBZ})<\operatorname{mixture} 1(\mathrm{AMPA}+\mathrm{MP}+$ CBZ) $<$ mixture $4($ AMPA + MP). However, there was no statistical difference in their range of toxicity for each bioassay (Kruskal-Wallis tests, $p>0.05$ ); the ternary mixture did not appear as the most toxic cocktail.

On the basis of $\mathrm{EC}_{50 \mathrm{~s}}$ (recalculated in $\mathrm{mg} . \mathrm{L}^{-1}$ according to the environmental values), all the mixtures were found to be more toxic to the three species than the chemicals applied alone. There was a high variability in the SR ratios ranging from 0.09 to 144 (Table 4). In the green algae, most SR ratios calculated with reference to CBZ, AMPA and MP agreed with the model of synergism action ( $\mathrm{SR}>1$ ); by contrast a model of additive action was suggested in the case of MP in the ternary mixture $(\mathrm{SR}=1)$. The synergistic ratios derived from the AMPA $+\mathrm{MP}$ mixture, and from the MP + CBZ mixture with reference to CBZ $(27<\mathrm{SRs}<144)$ were significantly higher than the other SR values $(\mathrm{SR}<10)$ indicating higher potency. In the daphnia, the joint-action toxicity of the ternary mixture and the AMPA + CBZ mixture agreed with antagonistic models, whatever the chemical of reference $(\mathrm{SR}<1)$; whereas the SR for 
the mixture $2(\mathrm{MP}+\mathrm{CBZ})$ and for the mixture 4 with reference to AMPA were consistent with a synergistic model ( $\mathrm{SR}>1)$. In the $C$. gigas metamorphosis bioassay, most mixtures fitted with an antagonistic model $(\mathrm{SR}<1)$; whereas in the embryotoxicity bioassay, both concepts of synergism and antagonism were observed according to the mixtures. The SR model revealed that the interactions were conformed to the model of synergism for all the mixtures with reference to AMPA, and for mixtures 2 and 4 (SR > 1), but the mixtures with reference of CBZ (mixtures 1 and 3) and MP (mixture 1) were rather antagonistic.

\section{Discussion}

\section{Occurrence of emerging pollutants in French northwest coastal waters}

From the pharmaceutical residues, psychotropic drugs (carbamazepine, oxazepam, venlafaxine) were the most represented therapeutic class in Normandy coastal waters. This was in agreement with data from Fabbri and Franzellitti (2016) showing the high prevalence of psychotropic drugs, such as antiepileptics, in seawater worldwide. Minguez et al. (2016) also found carbamazepine in relatively high concentrations in the summers 2011 and 2012 further east along the Normandy coastline (i.e. $>20 \mathrm{ng} . \mathrm{L}^{-1}$ in the Orne river, $2.3 \mathrm{~km}$ downstream the point of release of the main wastewater treatment plant of the city of Caen; $1.9 \mathrm{ng} . \mathrm{L}^{-1}$ in a marine estuary at $17 \mathrm{~km}$ downstream the same treatment plant), which highlighted the potential influence of urban discharges and tourism on pharmaceutical concentrations. Carbamazepine concentrations can also reach 132 ng. $\mathrm{L}^{-1}$ and $228 \mathrm{ng} . \mathrm{L}^{-1}$ in the Seine and Loire estuaries, respectively (AESN-AQUASCOP 2008). We also quantified the antidepressant venlafaxine in seawater, at a non-negligible level (1.13 ng. $\mathrm{L}^{-1}$ in average). Compared to nine other antidepressants (e.g. sertraline, paroxetine, duloxetine, clomipramine, etc.), venlafaxine was found to be also the most prevalent antidepressant in the Orne river 
(reaching 4.8 ng. $\mathrm{L}^{-1}$ ), and was still detected at sea at a concentration of $1.3 \mathrm{ng} . \mathrm{L}^{-1}$ (Minguez et al. 2016). Interestingly, the concentrations of biocides, and of methylparaben and triclosan particularly, were higher at Meuvaines than at Ver-sur-Mer. Meuvaines is a small rural village (population of 156 inhabitants) where agriculture represents $40.5 \%$ of the local activity (e.g. cereal crop, sugar beet cultures and cattle farming; INSEE 2011) and where biocides may be widely used in breeding and raising livestock. In addition, any pesticide was detected at the time of the environmental monitoring (punctual sampling in October 2014). Polar pesticides are not regularly monitored in the marine environment, in part, because of the analytical challenge due to the compounds' chemical properties (i.e., amphoteric characteristics). In addition, marine waters are usually complex matrices and contaminants are present at low concentrations which require accurate methods of quantification. It also highlighted the need to use more integrative sampling methods using passive sampling device (e.g. POCIS) that allow in situ collection of a time-integrated average of hydrophilic organic compounds. However, AMPA was the herbicidal product the most frequently detected in seawater at Meuvaines (Bouchart and Houssin 2015). AMPA concentrations averaged $0.5 \mu$ g.L $\mathrm{L}^{-1}$ in seawater at Meuvaines over a period of 10 months the same year (based on a monthly monitoring from February to November 2014) with a peak of $1.8 \mu \mathrm{g} . \mathrm{L}^{-1}$ in April (Bouchart and Houssin 2015). The difference of levels between April (maximum) and October (absence; our study) also suggested that the use of pesticides and thus, the pesticide runoff, varied across the year. The highest presence of AMPA in coastal waters in spring is likely to correlate with a period of high agricultural activities in spring and to its leaching to coastal waters. On the other hand, glufosinate was detected once in February 2014 at a concentration of $100 \mathrm{ng} . \mathrm{L}^{-1}$ (Bouchart and Houssin 2015). 


\section{Evaluation of single toxicity}

The classification of the Commission of the European Communities (1996) considered compounds as very toxic for aquatic organisms when $\mathrm{EC}_{50}<1 \mathrm{mg} . \mathrm{L}^{-1}$, toxic when $1 \mathrm{mg} . \mathrm{L}^{-1}<$ $\mathrm{EC}_{50}<10 \mathrm{mg} \cdot \mathrm{L}^{-1}$, harmful when $10 \mathrm{mg} . \mathrm{L}^{-1}<\mathrm{EC}_{50}<100 \mathrm{mg} . \mathrm{L}^{-1}$, and harmless when $\mathrm{EC}_{50}>$ $100 \mathrm{mg} \cdot \mathrm{L}^{-1}$. Based on nominal concentrations, the biocide triclosan was very toxic to all the species studied since the acute toxicity data were harvested from concentrations below 1 mg. $\mathrm{L}^{-1}$. In the same class, the preservative methylparaben showed either toxic or a harmful proclivity for the oyster metamorphosis test and for the three other bioassays, respectively. The toxicity of AMPA and carbamazepine varied from harmful to harmless according to the species studied. Finally, the toxicity of the anxiolytic venlafaxine varied strongly between very toxic for oyster larvae to harmful for algae and daphnia. In addition, these results showed that early-life stages of $C$. gigas were generally more sensitive than freshwater species (24-36 h-EC 50 in $C$. gigas < 48-72 h-EC 50 in $P$. subcapitata and D. magna) which supported previous data regarding the toxicity of antidepressants such as fluoxetine, sertraline and clomipramine (Minguez et al. 2014a). In this study, the authors reported a sensitivity gradient between seven aquatic species (4 marine species including $C$. gigas, and 3 freshwater species such as $P$. subcapitata and D. magna) and showed that the most sensitive tests were those performed with the bivalve $C$. gigas and the marine microalgae Skeletonema marinoi. The impacts of pollutants on the Pacific oyster are particularly of concern. Indeed, Crassostrea gigas is a filter-feeding mollusk which dominates the marine bivalve production worldwide. For example in the year 2011-2012, C. gigas dominates the production of oysters in France representing $98.9 \%$ of the total production (Comité National de la Conchyliculture 2016). Thus a toxic effect at the larval level may induce potentially important population and economic consequences. It therefore suggested that the embryo-larval development and 
metamorphosis in $C$. gigas larvae are sensitive endpoints for ecotoxicological assessment, and are important to consider in addition to regulatory model organisms.

Because of the absence of measured concentrations in the testing vessels during the exposures, we used the nominal concentrations instead of analytically measured ones to determine toxicity values which is a method regularly used in literature (e.g., Orvos et al. 2002; Kim et al. 2007; Terasaki et al. 2009; Bazin et al. 2010). In addition, as we did not know the persistency of the compounds, three bioassays were performed in total darkness and/or with glass vessels to avoid photolysis and sorption as much as possible. Overall, there is little information on the degradation (both biotic and abiotic) of these chemicals in such experimental devices. However, Orvos et al. (2002) reported a high level of recovery of triclosan during the 72 h-toxicity test with the algae Scenedesmus subspicatus under a constant light regime. On the other hand, the study of Aranami and Readman (2007) showed that triclosan in 2-L glass bottles was sensitive to irradiation in seawater (about $40 \%$ of disappareance after 72h-irradiation) whereas degradation was absent in darkness for 12 days. Interestingly, parabens did not appear so persistent in static systems (Yamamoto et al. 2011) whereas Terasaki et al. (2009) did not show a significant degradation of methylparaben in their 48h-D. magna bioassays with a photoperiod of 16-8 light-dark cycle and the latest found a similar $\mathrm{EC}_{50}$ value (average nominal value of $62 \mathrm{mg} \cdot \mathrm{L}^{-1}$ ). Mottier et al. (2013) also showed a good recovery of AMPA both in glass pillboxes and in culture plates in the 36 h-oyster embryotoxicity and 24 h-metamorphosis bioassays. In addition, it can be said that carbamazepine seems to be relatively persistent, and especially towards direct photolysis (Challis et al. 2014). 


\section{Acute effects of pharmaceuticals}

The literature review demonstrates a lack of ecotoxicological data for pharmaceuticals, and particularly for psychotropic drugs. Using immobilization as endpoint and based on nominal concentrations, the $48 \mathrm{~h}-\mathrm{EC}_{50}$ of carbamazepine in D. magna exceeded $100 \mathrm{mg} . \mathrm{L}^{-1}$ which was corroborated by three recent studies (Cleuvers 2003; Kim et al. 2007; Minguez et al. 2016). On the other hand, an other study showed $\mathrm{EC}_{50}$ values reaching approximately $13.8 \mathrm{mg} . \mathrm{L}^{-1}$ after $48 \mathrm{~h}$ of exposure (Ferrari et al. 2003). In the algae $P$. subcapitata, toxicity data about growth inhibition were above $100 \mathrm{mg} . \mathrm{L}^{-1}$ after $72 \mathrm{~h}$ of exposure, which was supported by the study of Minguez et al. (2016) reporting $72 \mathrm{~h}-\mathrm{EC}_{50}>100 \mathrm{mg} \cdot \mathrm{L}^{-1}$. Ferrari et al. (2003) also showed 96 h-NOEC and LOEC higher than $100 \mathrm{mg} . \mathrm{L}^{-1}$ as well. As a comparison, the growth of another algae species, D. subspicatus, was inhibited from $74 \mathrm{mg} . \mathrm{L}^{-1}$ after $72 \mathrm{~h}$-exposure to carbamazepine (Cleuvers 2003). The acute toxicity of venlafaxine reached $141.28 \mathrm{mg} . \mathrm{L}^{-1}$ in D. magna and $47.58 \mathrm{mg} . \mathrm{L}^{-1}$ in P. subcapitata after $48 \mathrm{~h}$ and $72 \mathrm{~h}$ of exposure, respectively (Minguez et al. 2014b, 2016).

There is no data available for carbamazepine and venlafaxine toxicity in marine bivalves, but using the same larval bioassays in C. gigas, a previous study showed that acute toxicity of antidepressants (fluoxetine, sertraline, etc.) was ranged between 0.067 to up to $1 \mathrm{mg} . \mathrm{L}^{-1}$ (Di Poi et al. 2014). In Mytilus galloprovincialis embryotoxicity test, the $\mathrm{EC}_{50}$-value was 0.21 $\mu \mathrm{g} . \mathrm{L}^{-1}$ for sertraline (Estévez-Calvar et al. 2016). Aguirre-Martínez et al. (2015) also showed that acute toxicity of the pharmaceuticals ibuprofen, carbamazepine, novobiocin and caffeine, was in the order of $\mathrm{mg} \cdot \mathrm{L}^{-1}$ for bacteria bioluminescence, microalgae growth inhibition and urchin fertilization. However, teratogenicity was observed in Paracentrotus lividus after exposure to environmental concentrations of drugs at $10 \mathrm{ng} . \mathrm{L}^{-1}$; at this concentration, carbamazepine and ibuprofen were found to reduce significantly the embryo-larval 
development. Taken together, these data showed that pharmaceuticals, and particularly antidepressant drugs (e.g., venlafaxine), can be very toxic to marine invertebrates. In addition, some compounds showing no ecological risk (Minguez et al. 2016) and displaying a moderate hydrophobicity (e.g., carbamazepine with a $\log \mathrm{K}_{\mathrm{ow}}>2.45$ ), can potentially bioaccumulate (Ferrari et al. 2004). Such pharmaceuticals are likely to exert long-term effects which cannot be detected after short-term exposures.

\section{Acute effects of pesticides}

D. magna and P. subcapitata are two biological models that have classically been used to guide European legislation on contaminants including pesticides (Agritox 2016). In our study, AMPA did not appear highly toxic to the green alga and daphnia $\left(\mathrm{EC}_{50}\right.$-values $\left.>100 \mathrm{mg} . \mathrm{L}^{-1}\right)$. Compared to glyphosate, limited $\mathrm{EC}_{50}$ data are available for AMPA, but available values were higher than $100 \mathrm{mg} . \mathrm{L}^{-1}$ (e.g. $\mathrm{EC}_{50}$-value $=690 \mathrm{mg} \cdot \mathrm{L}^{-1}$ for the immobilization test in daphnia; Agritox 2016; PPDB 2016) which supported our results. On the other hand, $\mathrm{EC}_{50}$-values were lower for oyster early-life stages and were comprised between 50 and $80 \mathrm{mg} . \mathrm{L}^{-1}$ (nominal values). In the same laboratory conditions, Mottier et al. (2013) reported similar nominal $\mathrm{EC}_{50}$ values, which were $40.62 \mathrm{mg} . \mathrm{L}^{-1}$ and higher than $100 \mathrm{mg} . \mathrm{L}^{-1}$ for the embryotoxicity and the metamorphosis tests, respectively. As a comparison, Akcha et al. (2012) showed that glyphosate, whose degradation product is AMPA, had no effect on oyster development at low tested concentrations ( 0.5 to $\left.5.0 \mu \mathrm{g} . \mathrm{L}^{-1}\right)$. Mottier et al. (2013) reported later that the acute toxicity of glyphosate ranged between $28 \mathrm{mg} \cdot \mathrm{L}^{-1}$ (embryo-larval development) to higher than $100 \mathrm{mg} . \mathrm{L}^{-1}$ (metamorphosis). 


\section{Acute effects of other biocides}

The biocides methylparaben and triclosan appeared as the most toxic chemicals to all organisms studied $\left(1 \mathrm{mg} . \mathrm{L}^{-1}<\mathrm{EC}_{50 \mathrm{~s}}<100 \mathrm{mg} . \mathrm{L}^{-1}\right.$ for methylparaben; $<1 \mathrm{mg} . \mathrm{L}^{-1}$ for triclosan). In the literature, acute toxicity of triclosan has been examined in aquatic invertebrates, fish, amphibians, algae and plants (Brausch and Rand 2011), and the data showed that this chemical was more toxic to similarly studied trophic groups in comparison to other disinfectants (triclocarban, biphenylol). In addition, the same authors reported that for all disinfectants studied, invertebrates are only slightly more sensitive than fish for acute time periods.

The ecotoxicological values that stem from our study were corroborated with literature in $D$. magna. When nominal concentrations were used, the $48 \mathrm{~h}-\mathrm{EC}_{50} \mathrm{~s}$ reached $0.397 \mathrm{mg} . \mathrm{L}^{-1}$ for triclosan (Orvos et al. 2002), and ranged from 54 mg.L ${ }^{-1}$ (Bazin et al. 2010) to $62 \mathrm{mg} . \mathrm{L}^{-1}$ (Terasaki et al. 2009) for methylparaben. Yamamoto et al. (2011) used analytically measured concentrations to determine toxicity values and reported a 48 h-effective concentration of 34 mg. $\mathrm{L}^{-1}$ for methylparaben which was the least toxic paraben amongst six other forms (e.g. nbutylparaben, n-propylparaben, benzylparaben).

In P. subcapitata, 72 h-growth $\mathrm{EC}_{50}$ s were of $0.025 \mathrm{mg} . \mathrm{L}^{-1}$ and $35.25 \mathrm{mg} . \mathrm{L}^{-1}$ for triclosan and methylparaben, respectively, which were close to published data reaching $0.53 \mathrm{mg} . \mathrm{L}^{-1}$ (nominal value) for triclosan in Yang et al. (2008) and $80 \mathrm{mg} \cdot \mathrm{L}^{-1}$ (measured value) for methylparaben in Yamamoto et al. (2011). Moreover, our data coupled with the literature confirmed that triclosan was the most toxic biocidal compound. Our results showed that green algae appeared more sensitive to triclosan than daphnia. High triclosan sensitivity in algae is likely due to the antibacterial characteristics of the compounds which disrupt lipid synthesis (McMurry et al. 1998), destabilize membrane (Lyrge et al. 2003; Franz et al. 2008) or uncouple oxidative phosphorylation (Newton et al. 2005) and that are similar between algae 
and bacteria (Coogan et al. 2007). Furthermore, it can be seen that even if measured concentrations were lacking in our study, methylparaben is classified similarly (i.e. as harmful) based on both nominal and analytical $\mathrm{EC}_{50}$-values in freshwater species.

For the first time, C. gigas embryotoxicity and metamorphosis tests have been used in order to assess the toxicity of biocides and showed that oyster larvae were particularly sensitive to triclosan. As a comparison in the marine mussel Perna perna, the mean inhibition concentrations of triclosan were $0.490 \mathrm{mg} . \mathrm{L}^{-1}\left(1 \mathrm{~h}-\mathrm{IC}_{50}\right)$ for fertilization, and $0.135 \mathrm{mg} . \mathrm{L}^{-1}$ for the embryo-larval development (48 h-IC 50 (Cortez et al. 2012). Based on limited environmental concentration and toxicity data, it appeared that biocidal compounds may cause adverse effects to aquatic organisms at concentrations as low as $5 \mu \mathrm{g} . \mathrm{L}^{-1}$ in $C$. gigas (our study). However, preliminary data on environmental concentrations suggested only a minimal risk to marine organisms as effect concentrations are generally 350 -fold higher than what has been observed in coastal seawaters.

\section{Toxicity of mixtures}

Because aquatic organisms are continuously exposed to complex mixtures of emerging contaminants, there is a need to evaluate mixture toxicity. When two or more chemicals are applied simultaneously to living organisms, the combined effect may result in the addition of toxic effect of one chemical to the other (non-interactive or additive action); or the toxic effects caused by the mixture being significantly less than the sum of the toxic effects of the separate constituents (antagonism model); or the toxic effects caused by the mixture may significantly exceed the sum of effects of the separate components (synergism model) (Stenersen 2004).

First, we showed that the ternary mixture was not the most toxic cocktail, and that the toxicity of all mixtures was in the same range (no statistical difference) for each bioassay. In addition, 
the comparative evaluation of the single and joint-toxicity of the chemicals based on the Synergistic Ratio model (Hewlett and Plackett 1959) revealed that the presence of methylparaben generally increased the toxicity of AMPA, with a particularly high potency in P. subcapitata. For all bioassay, the toxicity of carbamazepine and methylparaben was also enhanced in presence of each other (synergistic models except in the metamorphosis bioassay). However, the remaining data highlighted that evaluation of joint-toxic effects can be complex and that species-dependent mixture models can appear. As examples, we found that almost all mixtures fitted with a synergistic model in $P$. subcapitata, while these mixtures of molecules agreed with the antagonistic concept in oyster metamorphosis. In addition, the ternary mixture and the cocktail AMPA + CBZ agreed with either synergistic model in algae or antagonism in aquatic invertebrates. Compounds of a heterogeneous mixture often have different toxic sites and dissimilar modes of action such that concentration addition or synergism may not be expected (Broderius et al. 2004). Interestingly, Yang et al. (2008) published that binary mixtures of several antibacterial agents (e.g. triclosan, tylosin, triclocarban, tetracyclines), expecting to have the same mode of action, showed additive, synergistic, and even antagonistic effects in P. subcapitata. It has been reported that the types of interactions exhibited by the components of mixtures largely depend on the proportion of the occurrence in the mixtures (Otitoloju 2005). There is a lack of information on jointtoxicity and no agreed methods of dealing with mixtures which lead to difficult comparison between data. However as observed in our study, it was found that most of the mixtures studied, even with chemicals having different modes of action, act antagonistically or together in a synergistic fashion. Recent data reported that in vivo and chronic toxicity of pharmaceutical mixtures (10 most detected active pharmaceutical ingredients in the Tama river, Japan) may also deviate from concentration addition and/or independent action to produce synergistic effects (Watanabe et al. 2016). Numerous other examples of synergism 
are documented in the literature for mixtures of botanical pesticides, refine petroleum products, crude oil plus dispersants, or trace metals (e.g., Otitoloju 2003; Chukwuand and Okhumale 2009; Al-Jawasim et al. 2015; Ekpendu et al. 2016). Cleuvers (2003) also reported that combinations of various pharmaceuticals revealed stronger effects than expected from the effects measured singly. In addition, the mixture of carbamazepine and clofibrinic acid followed the concept of concentration addition in D. magna, while in the macrophyte Lemna minor, it acted with independent action. According to Backhaus (2014), the deviation from concentration addition/independent action may appear to be largely confined to mixtures of only a few compounds, whereas multicomponent mixture studies rarely observed synergistic or antagonistic mixture effects. The author suggested that this phenomenon might be explained by buffering against the impact of a few synergistic or antagonistic interactions.

We also showed that joint-action toxicity of the chemicals, and particularly in reference of AMPA and methylparaben, behaved differently in the two $C$. gigas bioassays. The toxicity of the molecules in the mixtures generally agreed with antagonistic models in pediveliger larvae (21 d-old, metamorphosis test); whereas most ratios showed synergistic interactions in Dlarvae (36h-old, embryotoxicity test). It could suggest sensitivity difference between life stages and/or differences of mode of action for the chemicals according to the maturity of the animals. In the Pacific oyster, young D-larvae were already found more sensitive to toxicological injuries due to exposure to several herbicides (Mottier et al. 2013) and antidepressants (Di Poi et al. 2014) than older organisms. Indeed, D larvae experience essential and costly developmental processes at this period of life (e.g., formation of morphological axes, rearrangement of cells) which might explain their highest sensitivity. 


\section{Conclusions}

As in their natural habitat, organisms are exposed not to a single chemical but simultaneously or sequentially to multiple mixtures of compounds, the present study investigated single and joint-effects of binary and ternary mixtures of several emerging substances. In summary, the results showed heterogeneity of the acute and sub-chronic toxicity of the tested molecules with the biocidal compounds (triclosan, methylparaben) being particularly toxic to freshwater and marine organisms contrary to the pesticide AMPA. Based on the $\mathrm{EC}_{50}$ values, acute effects seemed to be unlikely since the median toxicity concentrations were at minimum 10fold higher than actual environmental levels. However, significant combination effects of substances can occur even if the toxicity of the single substances is low. In our study, the toxicity of binary and ternary mixtures was not different but the mixtures were much more toxic than the chemicals singly, and eventually led to synergistic or antagonistic interactions. Our data were preliminary, and repeated testing and careful chemical analyses are necessary to confirm that these interactive effects occur consistently at these exposure concentrations. However, the realisation that a potentiation of toxicity could result when pollutants occur in mixtures underscores the need for an awareness of cocktail effects for better ecological risk assessment. In addition, our study also confirmed a higher sensitivity of bivalve larvae to chemicals compared to freshwater species (green algae, daphnia), and therefore highlights the importance of considering $C$. gigas bioassays in addition to regulatory standard tests in ecotoxicological studies.

\section{Acknowledgements}

This work was funded by the Direction de l'Agriculture et des Ressources Marines from the

Région Normandie (France). The authors acknowledge C. Dureule (Laboratoire LABEO 
Franck Duncombe) for the analytical analyses and A. Voisin-Anastasie (student at Unicaen) for his helpful assistance in animal testing. 


\section{References}

AFNOR (2009) Bio indicateur de la toxicité potentielle de milieux aqueux. Détermination de la toxicité potentielle d'échantillons aqueux sur le développement embryo-larvaire de bivalve. XP T90-382.

Agritox (2016). http://www.agritox.anses.fr/php/sa.php (accessed on November 2016).

Aguirre-Martínez GV, Owuor MA, Garrido-Perez C et al. (2015) Are standard tests sensitive enough to evaluate effects of human pharmaceuticals in aquatic biota? Facing changes in research approaches when performing risk assessment of drugs. Chemosphere 120:75-85.

Akcha F, Spagnol C, Rouxel J (2012) Genotoxicity of diuron and glyphosate in oyster spermatozoa and embryos. Aquat Toxicol 106-107:104-113.

Al-Jawasim M, Yu K, Park JW (2015) Synergistic effect of crude oil plus dispersant on bacterial community in a louisiana salt marsh sediment. FEMS Microbiol Lett 362(17):fnv144.

Alvarez-Muñoz D, Huerta B, Fernandez-Tejedor M et al. (2015a) Multi-residue method for the analysis of pharmaceuticals and some of their metabolites in bivalves. Talanta 136:174182.

Álvarez-Muñoz D, Rodríguez-Mozaz S, Maulvault AL et al. (2015b) Occurrence of pharmaceuticals and endocrine disrupting compounds in macroalgaes, bivalves, and fish from coastal areas in Europe. Environ Res Part B 143:56-64.

Amar E, Balsan D (2004) Les ventes d'antidépresseurs entre 1980 et 2001. Études et résultats, Direction de la Recherche, des Etudes, de l'Evaluation et des Statistiques (DREES) 285:1-8.

ANSM (2012) Analyse des ventes de médicaments en France en 2011. Agence Nationale de Sécurité du Médicament et des Produits de Santé 1-21.

Aranami K, Readman JW (2007) Photolytic degradation of triclosan in freshwater and seawater. Chemosphere 66:1052-1056.

Backhaus T (2014) Medicines, shaken and stirred: a critical review on the ecotoxicology of pharmaceutical mixtures. Phil Trans R Soc B 369:20130585.

Bazin I, Gadal A, Touraud E et al. (2010) Hydroxy Benzoate Preservatives (Parabens) in the Environment: Data for Environmental Toxicity Assessment. Environ Pollut 16:245-257.

Beausse J (2004) Selected drugs in solid matrices: a review of environmental determination, occurrence and properties of principal substances. TrAC 23:10-11.

Blaise C, Vasseur P (2005) Algal microplate toxicity test. In: Blaise C, Férard J-F (eds) Small-scale freshwater toxicity investigations. Springer, Berlin, pp 137-179.

Botta F, Lavison G, Couturier G et al. (2009) Transfer of glyphosate and its degradate AMPA to surface waters through urban sewerage systems. Chemosphere 77(1):133-139. 
Bouchart V, Houssin M (2015) Analyse des pathogènes et des éléments chimiques (essentiellement pesticides) dans les eaux et les huîtres de Normandie. Rapport d'étude Labéo Franck Duncombe, 53 p.

Boxall ABA, Rudd MA, Brooks BW et al. (2012) Pharmaceuticals and Personal Care Products in the Environment: What Are the Big Questions? Environ Health Perspect 120(9):1221-1229.

Brausch JM, Rand GM (2011) A review of personal care products in the aquatic environment: Environmental concentrations and toxicity. Chemosphere 82:1518-1532.

Broderius SJ, Kahl MD, Elonen GE et al. (2005) A comparison of the lethal and sublethal toxicity of organic chemical mixtures to the fathead minnow (Pimephales promelas). Environ Toxicol Chem 24:3117-3127.

Challis JK, Hanson ML, Friesen KJ, Wong CS (2014) A critical assessment of the photodegradation of pharmaceuticals in aquatic environments: defining our current understanding and identifying knowledge gaps. Environ Sci Processes Impacts 16:672-696.

Chiffre A, Degiorgi F, Buleté A et al. (2016) Occurrence of pharmaceuticals in WWTP effluents and their impact in a karstic rural catchment of Eastern France. Environ Sci Pollut Res 23:25427-25441.

Chukwuand LO, Okhumale BO (2009) Mode of joint action response to binary mixtures of three refined petroleum products by Nile tilapia Oreochromis niloticus fingerlings. Sci Res Essay 4(8):806-811.

Cleuvers M (2003) Aquatic toxicity of pharmaceuticals including the assessment of combination effects. Toxicol Lett 142:185-194.

Comité Nationale de la Conchyliculture (2016) http://www.cnc-france.com/La-Productionfrancaise.aspx (accessed on November 2016).

Commissariat Général au Développement Durable (2013) Contamination des cours d'eau par les pesticides en 2011. Rapport technique.

Commission of the European Communities (1996) Technical guidance document in support of commission directive 93/67/EEC on risk assessment for new notified substances and commission regulation (EC) No. 1488/94 on risk assessment for existing substances. Part II:environmental risk assessment. Office for Official Publications of the European Communities, Luxembourg.

Coogan MA, Edziyie RE, La Point TW, Venables BJ (2007) Algal bioaccumulation of triclocarban, triclosan, and methyl-triclosan in a North Texas wastewater treatment plant receiving stream. Chemosphere 67:1911-1918.

Coon SL, Bonar DB (1987) Pharmacological evidence that alpha 1-adrenoceptors mediate metamorphosis of the Pacific oyster, Crassostrea gigas. Neuroscience 23:1169-1174. 
Cortez FS, Seabra Pereira CD, Santos AR et al. (2012) Biological effects of environmentally relevant concentrations of the pharmaceutical Triclosan in the marine mussel Perna perna (Linnaeus, 1758). Environ Pollut 168:145-150.

Daughton CG, Ternes TA (1999) Pharmaceuticals and personal care products in the environment: agents of subtle change? Environ Health Perspect 107 (Suppl 6):907-938.

Di Poi C, Evariste L, Serpentini A et al. (2014) Toxicity of five antidepressant drugs on the embryo-larval development and metamorphosis in the Pacific oyster, Crassostrea gigas. Env Sci Pollut Res 21:13302-13314.

Dodson SI, Hanazato T (1995) Commentary on effects of anthropogenic and natural organic chemicals on development, swimming behavior, and reproduction of Daphnia, a key member of aquatic ecosystems. Environ Health Perspect 103(Suppl. 4):7-11.

Ekpendu EA, Saliu JK, Otitoloju AA (2016) The joint action effects of the binary mixtures of some botanical piscicides on post juvenile Clarias gariepinus. Intern J Fish Aquacult 8(2):2027.

EMEA (2006) Note for guidance on environmental risk assessment of medicinal products for human use. Doc Ref EMEA/CHMP/SWP/4447/00. Committee for Proprietary Medicinal Products. European Agency for the Evaluation of Medicinal Products, London, UK. http://www.emea.eu.int/pdfs/human/swp/444700en.pdf.

ENV/JM/MONO(2008)28 Comparaison between OECD test guidelines and ISO standards in the areas of ecotoxicological and health effects. Series on testing and assessment $\mathrm{N}^{\circ} 99,148 \mathrm{p}$.

Estévez-Calvar N, Canesi L, Montagna M et al. (2016) Adverse effects of the SSRI antidepressant sertraline on early life stages of marine invertebrates. Mar Environ Res S01411136(16)30090-3.

Fabbri E, Franzellitti S (2016) Human pharmaceuticals in the marine environment: Focus on exposure and biological effects in animal species. Environ Toxicol Chem 35(4):799-812.

Ferrari B, Mons R, Vollat B et al. (2004) Environmental risk assessment of six human pharmaceuticals: are the current environmental risk assessment procedures sufficient for the protection of the aquatic environment? Environ Toxicol Chem 23(5):1344-1354.

Ferrari B, Paxéus N, Lo Giudice R et al. (2003) Ecotoxicological impact of pharmaceuticals found in treated wastewaters: study of carbamazepine, clofibric acid, and diclofenac. Ecotoxicol Environ Saf 55(3):359-370.

Franz S, Altenburger R, Heilmaeir $\mathrm{H}$ et al. (2008) What contributes to the sensitivity of microalgae to triclosan? Aquat Toxicol 90:102-108.

Gaw S, Thomas KV, Hutchinson TH (2014) Sources, impacts and trends of pharmaceuticals in the marine and coastal environment. Phil Trans R Soc B 369(1656).

Giesy JP, Dobson S, Solomon KR (2000) Ecological risk assessment for Roundup ${ }^{\circledR}$ herbicide. Rev Environ Contam Toxicol 167:35-120. 
AESN-AQUASCOP (2008) Guide pratique des substances toxiques dans les eaux douces et littorales du bassin Seine-Normandie, pp. 11-12.

Halden RU, Paull DH (2005) Co-occurrence of triclocarban and triclosan in US water resources. Environ Sci Technol 39:1420-1426.

Hewlett PS, Plackett RL (1959) A unified theory for quantal responses to mixtures of drugs: non-interactive action. Biometrics 15:591-610.

Howe CM, Berrill M, Pauli BD et al. (2004) Toxicity of glyphosate-based pesticides to four north American frog species. Environ Tox Chem 23(28):1928-1938.

INSEE (2011) Connaissance Locale de l'Appareil Productif https://www.insee.fr (accessed on April 2017).

Kim Y, Choi K, Jung J et al. (2007) Aquatic toxicity of acetaminophen, carbamazepine, cimetidine, diltiazem and six major sulfonamides, and their potential ecological risks in Korea. Environ Int 33(3):370-375.

Köhler HR, Triebskorn R (2013) Wildlife Ecotoxicology of Pesticides: Can We Track Effects to the Population Level and Beyond? Science 341:759.

Kolpin DW, Furlong ET, Meyer MT et al. (2002) Pharmaceuticals, hormones, and other organic wastewater contaminants in U.S. streams, 1999-2000: a national reconnaissance. Environ Sci Technol 36(6):1202-1211.

Kolpin DW, Thurman EM, Lee EA et al. (2006) Urban contributions of glyphosate and its degradate AMPA to streams in the United States. Sci Tot Environ 354(2-3):191-197.

Lyrge H, Moe G, Skalevik R et al. (2003) Interaction of triclosan with eukaryotic membrane lipids. Eur J Oral Sci 111:216-222.

McMurry LM, Oethinger M, Levy SB (1998) Triclosan targets lipid synthesis. Nature 394:531-532.

Miner BE, De Meester L, Pfrender ME et al. (2012) Linking genes to communities and ecosystems: Daphnia as an ecogenomic model. Proc Biol Sci 279(1735):1873-1882.

Minguez L, Di Poi C, Farcy E et al. (2014a) Comparison of the sensitivity of seven marine and freshwater bioassays as regards antidepressant toxicity assessment. Ecotoxicology 23(9):1744-1754.

Minguez L, Farcy E, Ballandonne C et al. (2014b) Acute toxicity of 8 antidepressants: what are their modes of action? Chemosphere 108:314-319.

Minguez L, Pedelucq J, Farcy E et al. (2016) Toxicities of 48 pharmaceuticals and their freshwater and marine environmental assessment in northwestern France. Environ Sci Pollut Res Int 23(6):4992-5001. 
Mottier A, Kientz-Bouchart V, Serpentini A et al. (2013) Effects of glyphosate-based herbicides on embryo-larval development and metamorphosis in the Pacific Oyster, Crassostrea Gigas. Aquat Toxicol 128-129:67-78.

Munaron D, Tapie N, Budzinski H et al. (2012) Pharmaceuticals, alkylphenols and pesticides in Mediterranean coastal waters: results from a pilot survey using passive samplers. Est Coast and Shelf Sci 114:82-92.

Newton P, Cadena S, Rocha M et al. (2005) Effect of triclosan (TRN) on energy-linked functions of rat liver mitochondria. Toxicol Lett 160:49-59.

NF EN ISO 6341 (1996) Qualité de l'eau - Détermination de l'inhibition de la mobilité de Daphnia magna Straus (Cladocera, Crustacea) - Essai de toxicité aigüe (in French).

NF EN ISO 8692 (2012) Qualité de l'eau - Essai d'inhibition de la croissance des algues d'eau douce avec des algues vertes unicellulaires (in French).

NORMAN (Network of reference laboratories, research centres and related organisations for monitoring of emerging environmental substances) (2016) http://www.normandata.eu/ (accessed on April 2016).

OECD guidelines for the testing of chemicals $\mathrm{N}^{\circ} 201$ (2006) Freshwater alga and cyanobacteria, growth inhibition test.

Olié J, Omari FEL, Spadone C et al. (2002) Résultats d'une enquête sur l'usage des antidépresseurs en population générale française. Encéphale 28:411-417.

Orvos DR, Versteeg DJ, Inauen J et al. (2002) Aquatic toxicity of triclosan. Environ Toxicol Chem 21(7):1338-1349.

Otitoloju AA (2003) Relevance of joint action toxicity evaluations in setting realistic environmental safe limits of heavy metals. J Environ Manage 67(2):121-128.

Otitoloju AA (2005) Crude oil plus dispersant: Always a boon or bane? Ecotoxicology and Environ Saf 60:198-202.

PPDB (Pesticide Properties Database)

http://sitem.herts.ac.uk/aeru/ppdb/en/Reports/373.htm (accessed on November 2016).

Seiler RL, Zaugg SD, Thomas JM et al. (1999) Caffeine and pharmaceuticals as indicators of waste water contamination in wells. GroundWater 37(3):405-410.

Stenersen J (2004) Chemical pesticides: Mode of action and toxicology. Ast Edn, Crc Press, Boca Raton.

Tatarazako N, Oda S (2007) The water flea Daphnia magna (Crustacea, Cladocera) as a test species for screening and evaluation of chemicals with endocrine disrupting effects on crustaceans. Ecotoxicology 16(1):197-203. 
Terasaki M, Makino M, Tatarazako N (2009) Acute toxicity of parabens and their chlorinated by-products with Daphnia magna and Vibrio fischeri bioassays. J Appl Toxicol 29(3):242247.

Ternes TA (1998) Occurrence of drugs in German sewage treatment plants and rivers. Water Res 32:3245-3260.

Vindimian E (2012) MSExcel Macro Regtox 7.06 freely available from Eric Vindimian. IRSTEA, France. http://www.normalesup.org/*vindimian.fr_index.html.

von der Ohe PC, Schmitt-Jansen M, Slobodnik J et al. (2012) Triclosan-the forgotten priority substance? Environ Sci Pollut Res Int 19(2)585-591.

Watanabe H, Tamura I, Abe R et al. (2015) Chronic toxicity of an environmentally relevant mixture of pharmaceuticals to three aquatic organisms (alga, daphnid, and fish). Environ Toxicol Chem 35(4):996-1006.

Williams GM, Kroes R, Munro IC (2000) Safety evaluation and risk assessment of the herbicide Roundup and its active ingredient, glyphosate, for humans. Regul Toxicol Pharmacol 31(2 Pt 1):117-165.

Yamamoto H, Tamura I, Hirata Y et al. (2011) Aquatic toxicity and ecological risk assessment of seven parabens: Individual and additive approach. Sci Total Environ 410411:102-111.

Yang LH, Ying GG, Su HC et al. (2008) Growth-inhibiting effects of 12 antibacterial agents and their mixtures on the freshwater microalga Pseudokirchneriella subcapitata. Environ Toxicol Chem 27(5):1201-1208. 


\section{Caption for Figure}

Figure 1. Location of the two seawater collection sites (geographical coordinates: $49^{\circ} 20^{\prime} 38^{\prime \prime} \mathrm{N}$ $0^{\circ} 34^{\prime} 19^{\prime \prime} \mathrm{W}$ and $49^{\circ} 20^{\prime} 45^{\prime \prime} \mathrm{N} 0^{\circ} 31^{\prime} 99^{\prime \prime} \mathrm{W}$ ) for the quantification of emerging pollutants on the Northwestern French coast (Normandy, France). These sites are important regional oyster and cockle harvesting areas and are illustrated by the drops.

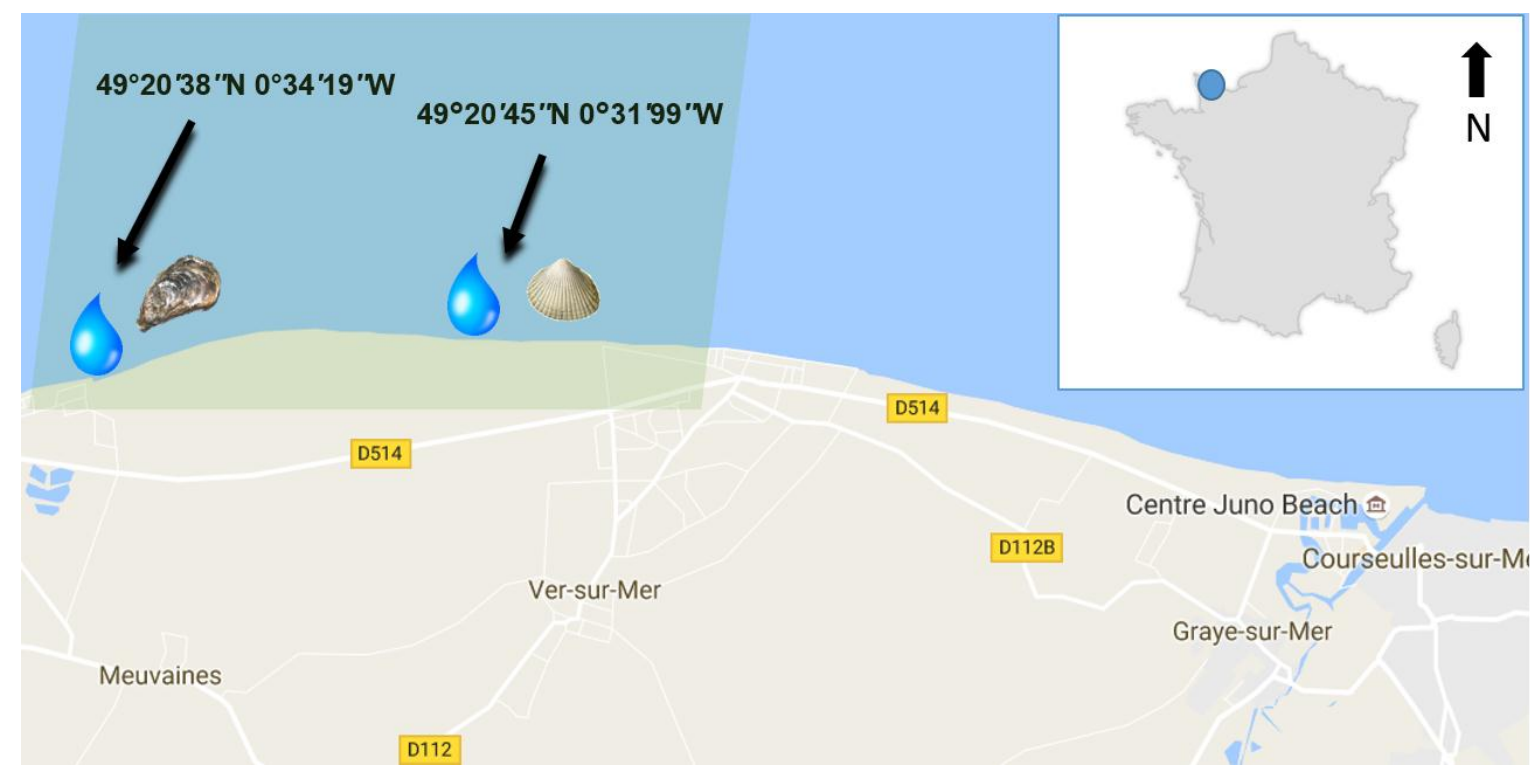


Table 1. Concentration quantification of emerging pollutants belonging to three chemical classes (pharmaceuticals, biocides, pesticides) in

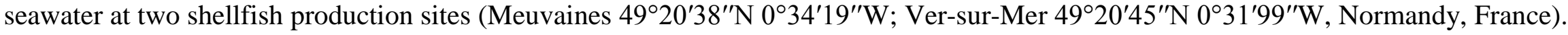

\begin{tabular}{|c|c|c|c|c|}
\hline \multirow[b]{2}{*}{ Compound class } & \multirow[b]{2}{*}{ Type } & \multirow[b]{2}{*}{ Linear molecular formula } & \multicolumn{2}{|l|}{ Sampling site } \\
\hline & & & $\begin{array}{l}\text { Meuvaines } \\
{[C]\left(\text { ng. } L^{-1}\right)}\end{array}$ & $\begin{array}{l}\text { Ver s/Mer } \\
{[C]\left(\text { ng.L } .^{-1}\right)}\end{array}$ \\
\hline \multicolumn{5}{|l|}{ Pharmaceuticals } \\
\hline Atenolol & beta-blocker & $\mathrm{C}_{14} \mathrm{H}_{22} \mathrm{~N}_{2} \mathrm{O}_{3}$ & $<l q(0.5)$ & $<l q(0.5)$ \\
\hline Carbamazepine & antiepileptic & $\mathrm{C}_{15} \mathrm{H}_{12} \mathrm{~N}_{2} \mathrm{O}$ & 0.96 & 1.01 \\
\hline Diclofenac & NSAID $^{*}$ & $\mathrm{C}_{14} \mathrm{H}_{11} \mathrm{Cl}_{2} \mathrm{NO}_{2}$ & $<l q(0.5)$ & $<l q(0.5)$ \\
\hline Ibuprofen & NSAID* & $\mathrm{C}_{13} \mathrm{H}_{18} \mathrm{O}_{2}$ & $<\operatorname{lq}(1.0)$ & $<l q(1.0)$ \\
\hline Ketoprofen & NSAID* & $\mathrm{C}_{16} \mathrm{H}_{14} \mathrm{O}_{3}$ & 1.56 & $<\operatorname{lq}(0.5)$ \\
\hline Metoprolol & beta-blocker & $\mathrm{C}_{15} \mathrm{H}_{25} \mathrm{NO}_{3}$ & $<l q(0.5)$ & $<l q(0.5)$ \\
\hline Oxazepam & anxyolitic & $\mathrm{C}_{15} \mathrm{H}_{11} \mathrm{ClN}_{2} \mathrm{O}_{2}$ & 1.47 & 1.74 \\
\hline Sulfamethoxazole & antibiotic & $\mathrm{C}_{10} \mathrm{H}_{11} \mathrm{~N}_{3} \mathrm{O}_{3} \mathrm{~S}$ & 1.47 & 1.60 \\
\hline Venlafaxine & antidepressant & $\mathrm{C}_{17} \mathrm{H}_{27} \mathrm{NO}_{2}$ & 1.45 & 0.81 \\
\hline \multicolumn{5}{|l|}{ Biocides } \\
\hline Benzylparaben & preservative & $\mathrm{C}_{14} \mathrm{H}_{12} \mathrm{O}_{3}$ & $<l q(1.0)$ & $<l q(1.0)$ \\
\hline Butylparaben & preservative & $\mathrm{C}_{11} \mathrm{H}_{14} \mathrm{O}_{3}$ & $<l q(1.0)$ & $<l q(1.0)$ \\
\hline Ethylparaben & preservative & $\mathrm{C}_{9} \mathrm{H}_{10} \mathrm{O}_{3}$ & 3.00 & 1.56 \\
\hline Isobutylparaben & preservative & $\mathrm{C}_{11} \mathrm{H}_{14} \mathrm{O}_{3}$ & $<l q(1.0)$ & $<l q(1.0)$ \\
\hline Isopropylparaben & preservative & $\mathrm{C}_{10} \mathrm{H}_{12} \mathrm{O}_{3}$ & $<\operatorname{lq}(1.0)$ & $<l q(1.0)$ \\
\hline Methylparaben & preservative & $\mathrm{C}_{8} \mathrm{H}_{8} \mathrm{O}_{3}$ & 18.59 & 3.64 \\
\hline Propylparaben & preservative & $\mathrm{C}_{10} \mathrm{H}_{12} \mathrm{O}_{3}$ & 2.95 & 0.87 \\
\hline Triclocarban & antimicrobial & $\mathrm{C}_{13} \mathrm{H}_{9} \mathrm{Cl}_{3} \mathrm{~N}_{2} \mathrm{O}$ & 1.75 & 0.18 \\
\hline Triclosan & antimicrobial & $\mathrm{C}_{12} \mathrm{H}_{7} \mathrm{Cl}_{3} \mathrm{O}_{2}$ & 14.23 & 4.02 \\
\hline \multicolumn{5}{|l|}{ Pesticides } \\
\hline Glyphosate & organophosphate & $\mathrm{C}_{3} \mathrm{H}_{8} \mathrm{NO}_{5} \mathrm{P}$ & $<l q(0.05)$ & $<l q(0.05)$ \\
\hline Aminomethylphosphonic acid (AMPA) & glyphosate degradate & $\mathrm{CH}_{6} \mathrm{NO}_{3}$ & $<\operatorname{lq}(0.05)$ & $<l q(0.05)$ \\
\hline Glufosinate & organophosphate & $\mathrm{C}_{5} \mathrm{H}_{12} \mathrm{NO}_{4} \mathrm{P}$ & $<\operatorname{lq}(0.05)$ & $<\operatorname{lq}(0.05)$ \\
\hline
\end{tabular}

with $<$ lq = limit of quantification (concentration limit in $n g . L^{-1}$ ).

${ }^{*}$ NSAID = NonSteroidal Anti-Inflammatory Drugs. 
Table 2. Toxicity of the chemicals for each endpoint evaluated by the values of $\mathrm{EC}_{10}$ (equivalent to the No Observed Effect Concentration), $\mathrm{EC}_{20}$ (equivalent to the Lo Observed Effect Concentration) and $\mathrm{EC}_{50}$ (effective concentration that affects $50 \%$ of the population) calculated on nominal concentrations by the Excel $^{\mathrm{TM}}$ macro REGTOX.

\begin{tabular}{|c|c|c|c|c|c|c|c|c|c|c|c|c|c|c|c|c|}
\hline \multirow[t]{4}{*}{ Test species } & \multirow[t]{4}{*}{ Endpoint } & \multirow{2}{*}{\multicolumn{3}{|c|}{$\begin{array}{l}\text { Pesticides } \\
\text { AMPA }\end{array}$}} & \multicolumn{6}{|c|}{ Antimicrobial preservatives } & \multicolumn{6}{|c|}{ Psychotropic drugs } \\
\hline & & & & & \multicolumn{3}{|c|}{ Methyl-paraben } & \multicolumn{3}{|c|}{ Triclosan } & \multicolumn{3}{|c|}{ Carbamazepine } & \multicolumn{3}{|c|}{ Venlafaxine } \\
\hline & & \multicolumn{3}{|c|}{$\mathrm{EC}_{\mathrm{x}}\left(\mathrm{mg} \cdot \mathrm{L}^{-1}\right)$} & \multicolumn{3}{|c|}{$\mathrm{EC}_{\mathrm{x}}\left(\mathrm{mg} \cdot \mathrm{L}^{-1}\right)$} & \multicolumn{3}{|c|}{$\mathrm{EC}_{\mathrm{x}}\left(\mathrm{mg} \cdot \mathrm{L}^{-1}\right)$} & \multicolumn{3}{|c|}{$\mathrm{EC}_{\mathrm{x}}\left(\mathrm{mg} \cdot \mathrm{L}^{-1}\right)$} & \multicolumn{3}{|c|}{$\mathrm{EC}_{\mathrm{x}}\left(\mathrm{mg} \cdot \mathrm{L}^{-1}\right)$} \\
\hline & & 10 & 20 & 50 & 10 & 20 & 50 & 10 & 20 & 50 & 10 & 20 & 50 & 10 & 20 & 50 \\
\hline $\begin{array}{l}\text { Marine species: } \\
\text { C. gigas }\end{array}$ & \multicolumn{10}{|c|}{ Marine species: } & & & & 0.45 & 0.57 & 0.87 \\
\hline & 24 h-metamorph & 27.08 & 39.80 & 76.90 & 1.24 & 2.46 & 7.88 & 0.09 & 0.15 & 0.34 & 10.78 & 14.22 & 22.83 & 0.04 & 0.09 & 0.31 \\
\hline D. magna & 48 h-immobil & $>100$ & $>100$ & $>100$ & 27.01 & 31.57 & 41.23 & 0.21 & 0.21 & 0.23 & $>100$ & $>100$ & $>100$ & $68^{*}$ & $89^{*}$ & $141.3^{*}$ \\
\hline
\end{tabular}

*data from L. Minguez (personal communication). 
Table 3. Toxicity of the mixtures evaluated for each endpoint by the values of $\mathrm{EC}_{10}$ (equivalent to the No Observed Effect Concentration), $\mathrm{EC}_{20}$ (equivalent to the Lo Observed Effect Concentration) and $\mathrm{EC}_{50}$ (effective concentration that affects $50 \%$ of the population) calculated on nominal concentrations by the Excel ${ }^{\mathrm{TM}}$ macro REGTOX. The unit X corresponds to the environmental concentration given in Table 1 . There was no statistical difference in toxicity between the four mixtures for each bioassay (Kruskal-Wallis tests).

\begin{tabular}{|c|c|c|c|c|c|c|c|c|c|c|c|c|c|}
\hline \multirow[t]{3}{*}{ Test species } & \multirow[t]{3}{*}{ Endpoint } & \multicolumn{3}{|c|}{$\begin{array}{l}\text { Mixture } 1 \\
\text { AMPA + MP + CBZ }\end{array}$} & \multicolumn{3}{|c|}{$\begin{array}{l}\text { Mixture } 2 \\
\mathrm{MP}+\mathrm{CBZ} \\
\end{array}$} & \multicolumn{3}{|c|}{$\begin{array}{l}\text { Mixture } 3 \\
\text { AMPA + CBZ }\end{array}$} & \multicolumn{3}{|c|}{$\begin{array}{l}\text { Mixture } 4 \\
\text { AMPA + MP }\end{array}$} \\
\hline & & \multicolumn{3}{|c|}{$\mathrm{EC}_{\mathrm{x}}(\mathrm{X})$} & \multicolumn{3}{|c|}{$\mathrm{EC}_{\mathrm{x}}(\mathrm{X})$} & \multicolumn{3}{|c|}{$\mathrm{EC}_{\mathrm{x}}(\mathrm{X})$} & \multicolumn{3}{|c|}{$\mathrm{EC}_{\mathrm{x}}(\mathrm{X})$} \\
\hline & & 10 & 20 & 50 & 10 & 20 & 50 & 10 & 20 & 50 & 10 & 20 & 50 \\
\hline \multicolumn{8}{|l|}{ Marine species: } & 25,177 & 36,932 & 71,097 & 147.0 & 769.0 & 12,981 \\
\hline & 24 h-metamorph & 29,970 & 57,498 & 175,157 & 32,298 & 113,076 & 963,100 & 77,633 & 113,880 & 219,227 & 19,353 & 36,816 & 158,124 \\
\hline \multicolumn{14}{|c|}{ Freshwater species: } \\
\hline P. subcapitata & 72 h-growth & 49.4 & 708.6 & 67,227 & 617.5 & 8,045 & 647,754 & 66.0 & 988.0 & 100,893 & 13.3 & 81.4 & 1,793 \\
\hline D. magna & 48 h-immobil & 241,853 & 252,573 & 272,012 & 515,496 & 641,031 & 930,445 & 256,635 & 267,513 & 287,187 & 99,999 & 105,528 & 115,697 \\
\hline
\end{tabular}

AMPA = aminomethylphosphonic acid, MP = methylparaben, and CBZ = carbamazepine. 
Table 4. Synergistic ratios (SR) of binary and ternary mixtures calculated according to the synergistic ratio model (Hewlett and Plackett 1959) for each endpoint, where $\mathrm{SR}=1$ describes that the joint action is additive; $\mathrm{SR}<1$ describes antagonism and SR $>1$ describes synergism.

\begin{tabular}{|c|c|c|c|c|c|c|}
\hline \multirow[t]{2}{*}{ Test species } & \multirow[t]{2}{*}{ Endpoint } & & \multirow{2}{*}{$\begin{array}{l}\text { Mixture } 1 \\
\mathrm{AMPA}+\mathrm{MP}+\mathrm{CBZ} \\
\end{array}$} & \multirow{2}{*}{$\begin{array}{l}\text { Mixture } 2 \\
\mathrm{MP}+\mathrm{CBZ} \\
\end{array}$} & \multirow{2}{*}{$\begin{array}{l}\text { Mixture } 3 \\
\text { AMPA + CBZ } \\
\end{array}$} & \multirow{2}{*}{$\begin{array}{l}\text { Mixture } 4 \\
\text { AMPA + MP } \\
\end{array}$} \\
\hline & & & & & & \\
\hline \multicolumn{7}{|l|}{ Marine species: } \\
\hline \multirow[t]{6}{*}{ C. gigas } & \multirow{3}{*}{$\begin{array}{l}36 \mathrm{~h}- \\
\text { embryotoxicity }\end{array}$} & $\mathrm{CBZ}$ & 0.77 & 4.76 & 0.49 & - \\
\hline & & AMPA & 2.24 & - & 1.43 & 7.55 \\
\hline & & MP & 0.82 & 5.06 & - & 2.76 \\
\hline & \multirow{3}{*}{$\begin{array}{l}24 \mathrm{~h}- \\
\text { metamorphosis }\end{array}$} & $\mathrm{CBZ}$ & 0.25 & 1.25 & 0.21 & - \\
\hline & & AMPA & 0.85 & - & 0.70 & 0.94 \\
\hline & & MP & 0.09 & 0.43 & - & 0.10 \\
\hline \multicolumn{7}{|c|}{ Freshwater species: } \\
\hline \multirow[t]{3}{*}{ P. subcapitata } & \multirow{3}{*}{$\begin{array}{l}72 \mathrm{~h}- \\
\text { growth }\end{array}$} & $\mathrm{CBZ}$ & 9.35 & 26.52 & 6.46 & - \\
\hline & & AMPA & 3.83 & - & 2.65 & 143.95 \\
\hline & & MP & 1.01 & 2.86 & - & 37.95 \\
\hline \multirow[t]{3}{*}{ D. magna } & \multirow{3}{*}{$\begin{array}{l}48 \mathrm{~h}- \\
\text { immobilization }\end{array}$} & CBZ & 0.71 & 5.66 & 0.70 & - \\
\hline & & AMPA & 0.71 & - & 0.70 & 1.67 \\
\hline & & MP & 0.29 & 2.33 & - & 0.69 \\
\hline
\end{tabular}

AMPA = aminomethylphosphonic acid, MP = methylparaben, and CBZ = carbamazepine. 